\title{
Bedload geochemical and petrophysical signature of the Algal and Bohemian streams, James Ross Island, Antarctic Peninsula
}

\author{
Simona Sroková, Daniel Nývlt \\ Polar-Geo-Lab, Department of Geography, Faculty of Science, Masaryk University, \\ Kotlářská 2, Brno, Czech Republic
}

\begin{abstract}
This study presents the first geochemical and petrophysical data on the composition of the bedload sediments transported by the Algal and Bohemian Stream, and the latter's prominent tributary: the Dirty Stream. The catchments of these rivers are partially glacierised, with only $2 \%$ and $6 \%$ ice cover in the Algal and Bohemian stream catchments, respectively. Therefore, the primary sources of liquid water to these rivers are snowmelt and active layer thawing. This study shows that the Cretaceous marine sedimentary rocks deposited in the back-arc James Ross Basin, which underlies the studied rivers, represent the main constituent of fluvial bedload. This is in contrast to suspended sediment loads, whose composition is a mixture of volcanic rocks from the surrounding James Ross Island Volcanic Group. This also suggests that bedload is only transported for a distance of few hundreds of metres, while suspended sediment load is transported throughout the Algal and Bohemian streams to the sea. It is anticipated that this work will serve as the source of data for further studies from fluvial geomorphology to river ecology.
\end{abstract}

Key words: proglacial stream, fluvial sediments, suspended load, bedrock lithology, icefree Antarctic environment

DOI: $10.5817 / \mathrm{CPR} 2021-2-14$

\section{Introduction}

The nature of the Antarctic Peninsula (AP) is affected by ongoing climatic and environmental change(Vaughan et al. 2003, Siegert et al. 2019). Rising atmospheric temperatures since the mid- $20^{\text {th }}$ century has led to a significant loss of ice mass; including the breakup of ice shelves (Cook and Vaughan 2010, Paolo et al. 2015) and the retreat of land-terminating glaciers (Pritchard and Vaughan 2007, Engel et al.

Received October 29, 2021, accepted January 18, 2022.

*Corresponding author: D. Nývlt < daniel.nyvlt@sci.muni.cz>

Acknowledgements: This study was presented and successfully defended by SS as a BSc. thesis under the supervision of DN in 2019. The authors would like to thank the Czech Antarctic Research Programme and its crew for providing data and support during the austral summer of 2017 when the samples were collected by DN. This research was supported by Ministry of Education, Youth and Sports of the Czech Republic projects: Czech Polar Research Infrastructure project (LM2015078) and ECOPOLARIS (CZ.02.1.01/0.0/0.0/16_013/0001708). We appreciate the proofreading and further suggestions provided by Chris Stringer and the journal reviewers. 
2012, Seehaus et al. 2018). As these changes have occurred, the landscapes have shifted from glacial to paraglacial and periglacial processes (Davies et al. 2013, RuizFernández et al. 2019). This degradation of the cryosphere has resulted in greater fluvial activity (Kavan et al. 2017, Jennings and Hambrey 2021) and, therefore, a greater sediment transport into the Southern Ocean (Kavan et al. 2017, Falk and SilvaBusso 2021).

Ice-free areas in Antarctica provide unique opportunities to study the fluvial and sedimentary processes and interactions that will become more widespread across Antarctica in the future due to climate change. Some of the largest streams in the AP region are located on the Ulu Penin-

\section{Study area}

JRI is a largely glaciated island located in the Weddell Sea, to the east of the Trinity Peninsula (northern AP). The largest ice-free area is the Ulu Peninsula, which has an ice-free area of approx. $312 \mathrm{~km}^{2}$ (Hrbáček et al. 2017, Kavan et al. 2017). This is the location of the Czech J. G. Mendel Antarctic Station (JGM).

The JGM is located close to sea level in the northern sector of the Ulu Peninsula. The mean annual air temperature is around $-7^{\circ} \mathrm{C}$ (Hrbáček and Uxa 2020) and varied between $-4.5^{\circ} \mathrm{C}$ and $-9^{\circ} \mathrm{C}$ for the time period of 2005-2015 (Ambrožová et al. 2020). The region has an estimated 300 to $700 \mathrm{~mm}$ of water equivalent of precipitation per year (predominantly in the form of snow) (van Wessem et al. 2016, Palerme et al. 2017). However, prevailing southwesterly to southern winds (Kavan et al. 2020, Kňažková et al. 2021) strongly influence the distribution and drifting of snow, resulting in limited snow cover on flat surfaces (Hrbáček et al. 2016, Kňažko- sula, its largest ice-free area (Ondráčková et al. 2020, Jennings et al. 2021, Hrbáček et al. 2017, Kavan et al. 2017). Located on the northern part of James Ross Island (JRI), the Ulu Peninsula provides an excellent location to study the source-to-sink transport of fluvial sediments ( $c f$. Kavan et al. 2017, Ondráčková et al. 2020).

This study aims to contribute to the understanding of fluvial bedload dynamics in Antarctica's ice-free areas. Using petrophysical and geochemical data, this study will provide the first characterisation of the bedload of the Algal Stream and Bohemian Stream catchments in the context of their geological and environmental setting on the northernmost part of the Ulu Peninsula (Fig. 1).

vá et al. 2020). Snow patches are distributed irregularly and mostly fill depressions or appear on the lee-sides of slopes and obstacles (Nývlt et al. 2016, Kňažková et al. 2020).

The Ulu Peninsula is underlained by permafrost, with an active layer of 50 to $120 \mathrm{~cm}$ thickness (Hrbáček et al. 2017, 2019). The water in streams are principally sourced from snowmelt and the thawing of the active layer and glaciers (Kavan et al. 2017, Ondráčková et al. 2020). The deglaciation of low-lying areas started around $12.9 \mathrm{ka}$ (Nývlt et al. 2014) and higher parts of the catchments became ice-free during the first half of the Holocene between 10 and $6 \mathrm{ka}$ (Johnson et al. 2011, Glasser et al. 2014). This has provided sufficient time for river networks to develop. Their drainage pattern is primarily controlled by geological structures and exogenous geomorphological processes (Kavan et al. 2017, Mlčoch et al. 2020, Jennings et al. 2021). 


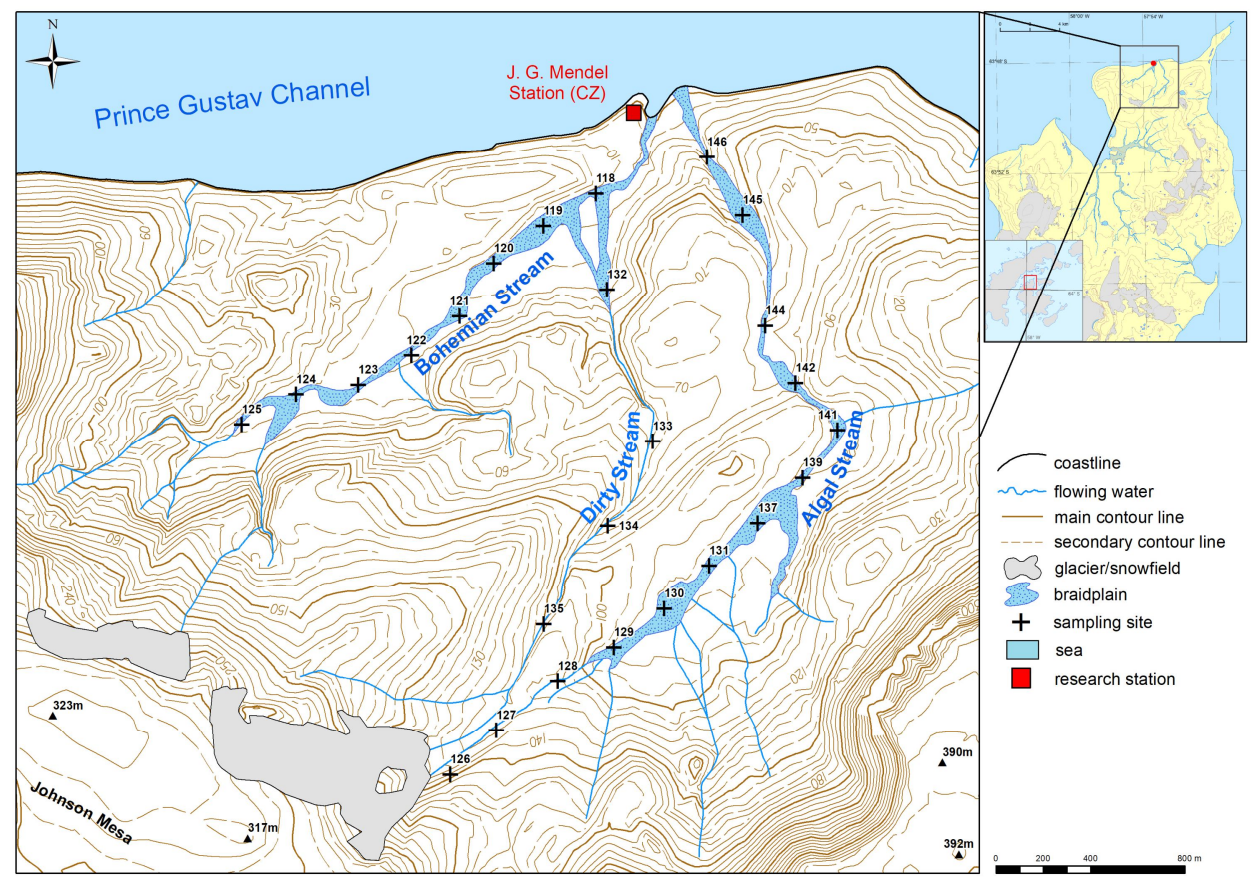

Fig. 1. Catchments of Algal, Bohemian, and Dirty streams with the locations at which samples were collected (topographic source CGS 2009 [1]; coordinate system WGS 1984 UTM Zone 21S).

The Algal and Bohemian streams are located to the north of the Ulu Peninsula (Fig. 1) and have adjacent outlets close to the JGM. The Bohemian Stream has a prominent tributary that enters to its east: the Dirty Stream. Both of these catchments have minimal glacier cover (Kavan et al. 2017). The basic morphometric parameters for both streams are summarised in
Table 1. The Bohemian Stream is a typical subsequent stream affected by the selective erosion of loose sedimentary strata. Similarly, the Algal and Dirty streams have subsequent reaches in the upper parts of their catchments but cut into the sedimentary strata in their lower courses (Kavan et al. 2017).

\begin{tabular}{|l|c|c|c|c|c|c|}
\hline & $\begin{array}{c}\text { area } \\
\left(\mathrm{km}^{2}\right)\end{array}$ & $\begin{array}{c}\text { glacierised } \\
\text { area }(\%)\end{array}$ & $\begin{array}{c}\text { mean } \\
\text { altitude } \\
(\mathrm{m})\end{array}$ & $\begin{array}{c}\text { mean } \\
\text { catchment } \\
\text { slope }\left(^{\circ}\right)\end{array}$ & $\begin{array}{c}\text { stream } \\
\text { length } \\
(\mathrm{km})\end{array}$ & $\begin{array}{c}\text { stream } \\
\text { gradient } \\
\left(\mathrm{m} . ~^{-1}\right)\end{array}$ \\
\hline Algal & 2.82 & 2 & 187.48 & 12.94 & 1.65 & 30.3 \\
\hline Bohemian & 6.47 & 6 & 131.9 & 10.37 & 3.26 & 39.9 \\
\hline
\end{tabular}

Table 1. Basic morphometric parameters for Algal and Bohemian streams (based on calculations in Kavan et al. 2017). 
Both catchments lie mostly on Cretaceous marine sediments deposited in the back-arc James Ross Basin (see Fig. 2; Kavan et al. 2017, Mlčoch et al. 2020). Only the upper reaches of the streams lie on volcanic rocks (James Ross Island Volcanic Group of Neogene age) (Smellie et al. 2013). In the lower reaches of both catchments, the Mendel Formation's Neogene sedimentary rocks crop out (Nývlt et al. 2011). The Cretaceous strata that outcrops in the Bohemian Stream catchment are composed of tabular sandstones and conglomerates from the Whisky Bay and Hidden Lake formations (Gustav Group) (Ineson et al. 1986, Mlčoch et al. 2020), while the finer-grained sandstones and mudstones of the Santa Marta Formation of the Marambio Group only crop out in Algal Stream catchment (Olivero et al.
1986, Mlčoch et al. 2020). The watershed between the catchments follows the cuesta composed of the more resistant upper Hidden Lake Fm. strata (Kavan et al. 2017). Outcrops of the James Ross Island Volcanic Group rocks are seen in the upper reaches of the studied catchments and are characterised by hyaloclastite breccias, basalt pillow lavas, caprocks and dykes, tuffs, lapillistones and volcaniclastic sandstones (Nehyba and Nývlt 2014, Altunkaynak et al. 2018, Mlčoch et al. 2020). The outcrops of the Mendel Formation sedimentary in the lower reaches of both catchments are composed of diamictites and tuffaceous sandstones to siltstones (Nývlt et al. 2011). Carbonate veins penetrate locally through the Cretaceous sedimentary rocks (Mlčoch et al. 2020).

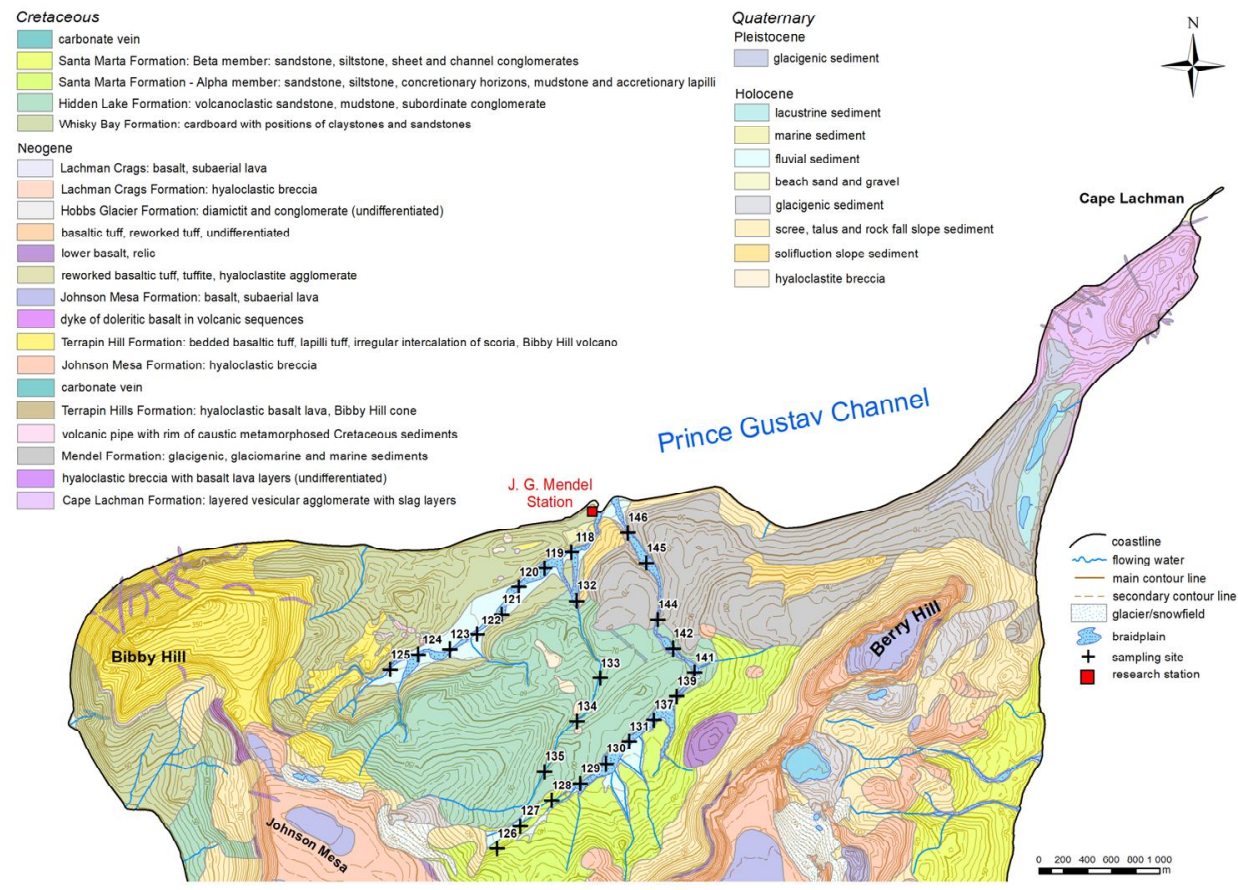

Fig. 2. The geology of the Algal and Bohemian streams catchments and their surroundings (modified from Mlčoch et al. 2020; coordinate system WGS 1984 UTM Zone 21S). 


\section{Material and Methods}

The samples that were analysed in this study were collected by DN at 25 sites (see Figs. 1 and 2). During the Czech Antarctic expedition in February 2017. All of the bedload samples were sieved (to $<2 \mathrm{~mm}$ in size) and dried at the JGM and then transported wrapped in zip lock bags to the Department of Geography, Faculty of Science, Masaryk University Brno, Czech Republic.

The chemical composition and provenance of the bedload samples was determined through magnetic susceptibility and elemental composition analysis. The samples were measured in zip lock bags, which did not affect the results derived from either technique. Magnetic susceptibility measurements were taken with a Kappabridge MFK1-FA (AGICO, Inc., Czech Republic) at the Polar-Geo-Lab,
Department of Geography, Masaryk University in Brno, Czech Republic. The samples were analysed at two frequencies (low: $976 \mathrm{~Hz}$ and high: $15616 \mathrm{~Hz}$ ) with a magnetic field of 200 A.m ${ }^{-1}$. The Kappabridge MFK1-FA allowed us to directly measure the mass-specific magnetic susceptibility and, with low and high-frequency measurements, it was possible to calculate the frequency-dependent magnetic susceptibility according to Dearing et al. (1996). Since the individual ratios of the mass-specific magnetic susceptibility $\left(\mathrm{MS}_{\mathrm{LF}}\right)$ had a range of values from 3.06 $10^{-7} \mathrm{~m}^{3} \mathrm{~kg}^{-1}$ to $69,37 \cdot 10^{-7} \mathrm{~m}^{3} \mathrm{~kg}^{-1}$, and the frequency-dependent magnetic susceptibility $\left(\mathrm{MS}_{\mathrm{FD}}\right)$ varied between $1.69 \%$ and $3.62 \%$ (see Fig. 3), the ratio values were normalised as values from 0 to 1 .

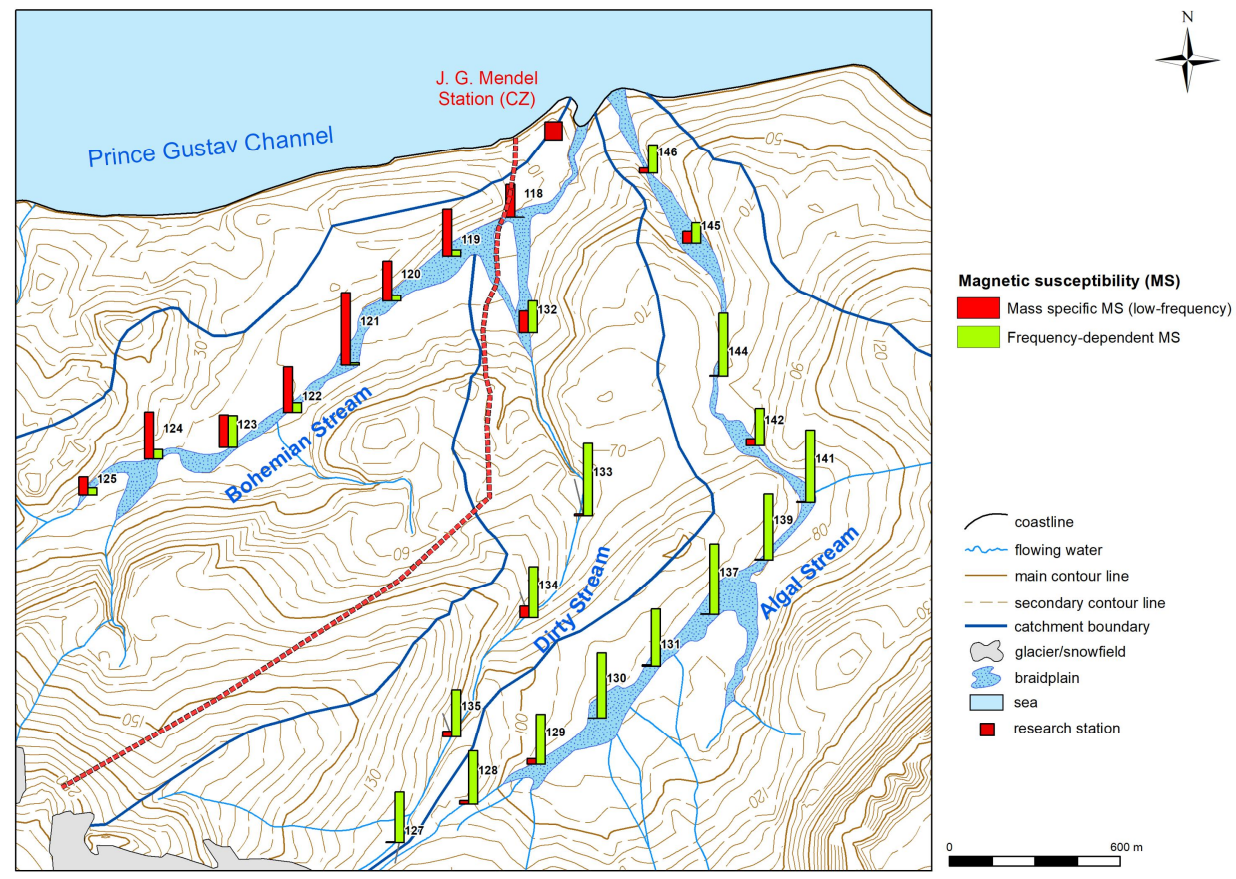

Fig. 3. Mass specific magnetic susceptibility (low-frequency) and frequency-dependent magnetic susceptibility of studied bedload samples from Algal, Bohemian, and Dirty streams (topographic source CGS 2009 [1]; coordinate system WGS 1984 UTM Zone 21S). 
Elemental composition was measured by X-ray fluorescence (XRF) using the handheld ED-XRF spectrophotometer Innov-X Delta Premium in Soil-Geochem/ Vanad mode. Each sample was measured three times and then averaged to determine an average elemental composition for each sample. Subsequently, the elemental ratios of $\mathrm{Al} / \mathrm{Si}, \mathrm{Rb} / \mathrm{Sr}, \mathrm{Ca} / \mathrm{Sr}, \mathrm{K} / \mathrm{Ca}$ and $\mathrm{Zr} / \mathrm{Ti}$ were calculated from average composition of each element. Since the individual ratios had a range of values from 0.03 to 61.38 , for a better graphical representation in Fig. 4, the ratio values were normalised (to maximum values) so that the data presented ranges from 0 to 1 .

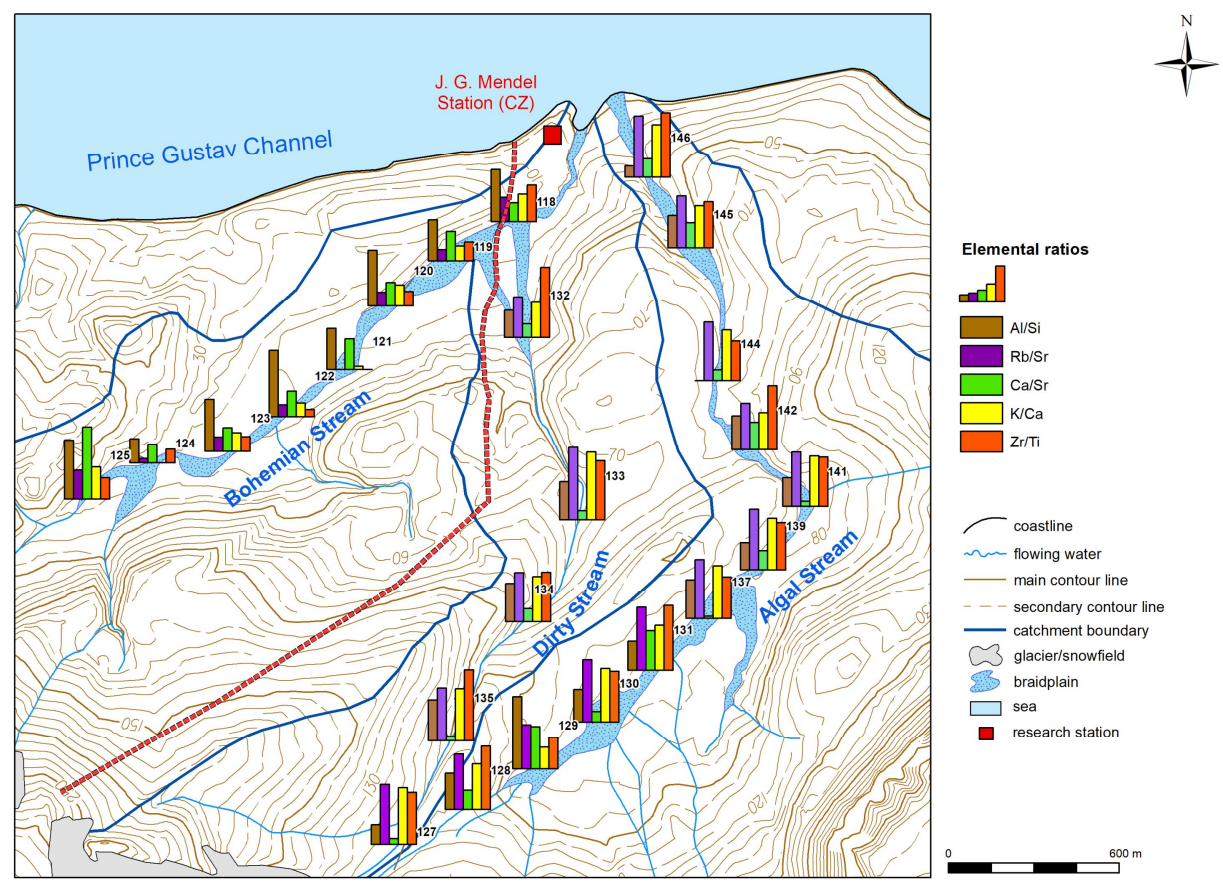

Fig. 4. Elemental ratios of studied bedload samples from Algal, Bohemian, and Dirty streams (topographic source CGS 2009 [1]; coordinate system WGS 1984 UTM Zone 21S).

\section{Results}

$\mathrm{MS}_{\mathrm{LF}}$ showed values in the order of $10^{-7}$ to $10^{-6} \mathrm{~m}^{3} \mathrm{~kg}^{-1}$ with a range from $3.06 \cdot 10^{-7} \mathrm{~m}^{3} \mathrm{~kg}^{-1}$ to $69.37 \cdot 10^{-7} \mathrm{~m}^{3} \mathrm{~kg}^{-1}$ (see Fig. 3). The lowest values were generally found in samples from the Algal and Dirty streams $\left(3.06 \cdot 10^{-7} \mathrm{~m}^{3} \mathrm{~kg}^{-1}\right.$ to $17.10 \cdot 10^{-7} \mathrm{~m}^{3}$. $\mathrm{kg}^{-1}$ ), especially in their upper reaches. In contrast, the samples from the Bohemian Stream generally showed higher $\mathrm{MS}_{\mathrm{LF}}$, ranging from $19.69 \cdot 10^{-7} \mathrm{~m}^{3} \mathrm{~kg}^{-1}$ to 69.37 $10^{-7} \mathrm{~m}^{3} \mathrm{~kg}^{-1}$, with the highest values (sample 121) found in the middle part of the Bohemian Stream (Fig. 3). There is a clear negative correlation between the $\mathrm{MS}_{\mathrm{LF}}$ and $\mathrm{MS}_{\mathrm{FD}}$ (Table 2), with higher values found for the Algal and Dirty streams sediments (2.23-3.62\%) and lower values for the Bohemian Stream sediments (1.69-2.54\%). 


\begin{tabular}{|c|c|c|c|c|c|c|c|c|c|c|c|c|}
\cline { 2 - 11 } \multicolumn{1}{c|}{} & $\mathbf{A l}$ & $\mathbf{S i}$ & $\mathbf{Z r}$ & $\mathbf{T i}$ & $\mathbf{F e}$ & $\mathbf{M n}$ & $\mathbf{R b}$ & $\mathbf{S r}$ & $\mathbf{C a}$ & $\mathbf{K}$ & $\mathbf{M S}_{\mathrm{FD}}$ & $\mathbf{M S}_{\mathbf{L F}}$ \\
\hline $\mathbf{A l}$ & 1.00 & 0.85 & -0.05 & 0.24 & 0.35 & 0.07 & -0.48 & 0.17 & 0.37 & -0.22 & -0.42 & 0.37 \\
\hline $\mathbf{S i}$ & & 1.00 & 0.03 & 0.16 & 0.08 & -0.17 & -0.23 & 0.06 & 0.15 & 0.04 & -0.24 & 0.18 \\
\hline $\mathbf{Z r}$ & & & 1.00 & 0.73 & 0.25 & 0.14 & -0.08 & 0.21 & 0.14 & -0.16 & -0.28 & 0.06 \\
\hline $\mathbf{T i}$ & & & & 1.00 & 0.78 & 0.60 & -0.68 & 0.67 & 0.69 & -0.72 & -0.65 & 0.63 \\
\hline $\mathbf{F e}$ & & & & & 1.00 & 0.81 & -0.94 & 0.83 & 0.91 & -0.92 & -0.75 & 0.88 \\
\hline $\mathbf{M n}$ & & & & & & 1.00 & -0.81 & 0.73 & 0.76 & -0.80 & -0.69 & 0.80 \\
\hline $\mathbf{R b}$ & & & & & & & 1.00 & -0.78 & -0.93 & 0.90 & 0.82 & -0.93 \\
\hline $\mathbf{S r}$ & & & & & & & & 1.00 & 0.86 & -0.83 & -0.65 & 0.89 \\
\hline $\mathbf{C a}$ & & & & & & & & & 1.00 & -0.93 & -0.79 & 0.93 \\
\hline $\mathbf{K}$ & & & & & & & & & & 1.00 & 0.68 & -0.86 \\
\hline $\mathbf{M S}$ & & & & & & & & & & & 1.00 & -0.82 \\
\hline $\mathbf{M S}$ & & & & & & & & & & & & 1.00 \\
\hline
\end{tabular}

Table 2. Matrix of correlation coefficients $(\mathrm{p}<0.05)$ of studied elements, low-frequency magnetic susceptibility and frequency-dependent magnetic susceptibility. Positive and negative correlations are highlighted in green and red, respectively.

As measured by XRF, the elemental composition of individual samples is given in Table 3, with the calculated elemental ratios cartographically visualised in Fig. 4. The samples that were collected from the Bohemian Stream showed high $\mathrm{Al} / \mathrm{Si}$ ratios (0.215-0.244), moderate to high $\mathrm{Ca} / \mathrm{Sr}$ ratios (50.594-61.385) and low to moderate $\mathrm{Rb} / \mathrm{Sr}, \mathrm{K} / \mathrm{Ca}$ and $\mathrm{Zr} / \mathrm{Ti}$ ratios $(0.112$ 0.193, 0.392-0.632, 0.029-0.037, respectively). In contrast, the samples from the Dirty Stream and Algal Stream showed low to moderate $\mathrm{Al} / \mathrm{Si}$ values (0.1980.248 ), moderate to high $\mathrm{Rb} / \mathrm{Sr}, \mathrm{K} / \mathrm{Ca}$ and
$\mathrm{Zr} / \mathrm{Ti}$ ratios $(0.226-0.314,0.553-0.932$, $0.036-0.044$, respectively) and low $\mathrm{Ca} / \mathrm{Sr}$ values (46.825-55.338).

A clear and large positive correlation $(>0.85)$ was observed between $\mathrm{Fe}$ and $\mathrm{Ca}$, $\mathrm{Al}$ and $\mathrm{Si}, \mathrm{Ca}$ and $\mathrm{Sr}$, and $\mathrm{Rb}$ and $\mathrm{K}$. Conversely, a high negative correlation was visible for $\mathrm{Ca}$ and $\mathrm{K}, \mathrm{Ca}$ and $\mathrm{Rb}$, or $\mathrm{Fe}$ and $\mathrm{K}$. The transitional metals (Mn, Fe, Ti) and alkaline earth metals $(\mathrm{Sr}, \mathrm{Ca})$ correlated positively with $\mathrm{MS}_{\mathrm{LF}}$. However, the alkali metals $(\mathrm{Rb}, \mathrm{K})$ showed a negative correlation with $\mathrm{MS}_{\mathrm{LF}}$ but correlated positively with $\mathrm{MS}_{\mathrm{FD}}$ (Table 2). 
F (n) అ゙

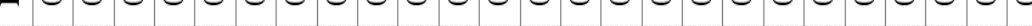
ஸ் ઇ ซ் 业

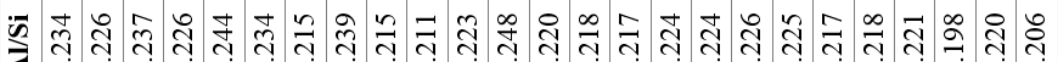
\.

ก.

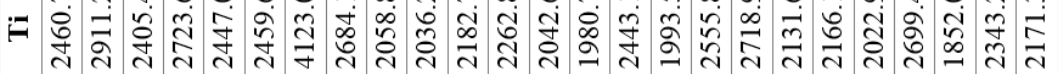

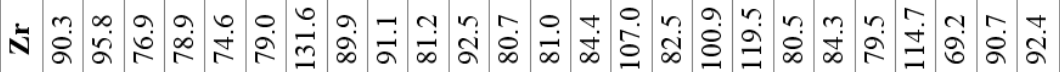

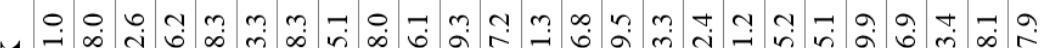

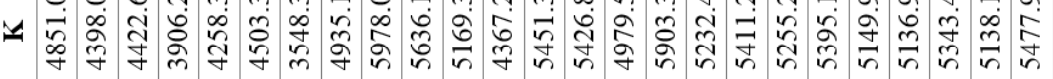

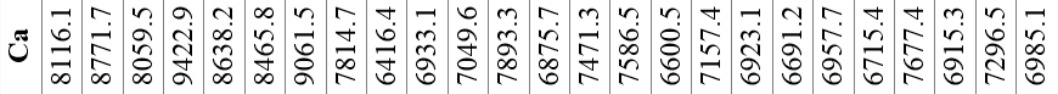

tr m $m$ m $m$ m $\infty$ m

ウ

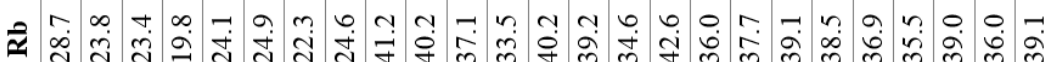

ナ 0 .

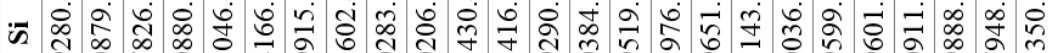
ปิ

m

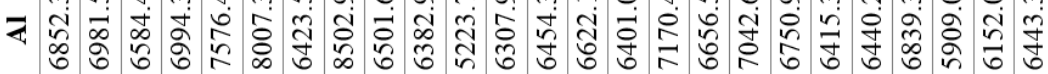

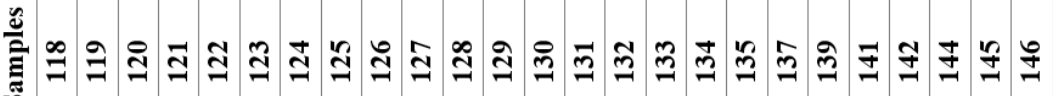




\section{Discussion}

The bedload samples from the Bohemian Stream are characterised by high $\mathrm{MS}_{\mathrm{LF}}$ and low $\mathrm{MS}_{\mathrm{FD}}$, which corresponds with the sand to pebble size of the grains in the underlying Cretaceous marine strata (Ineson et al. 1986). The exceptions to this are in samples 122-124 where slightly higher $\mathrm{MS}_{\mathrm{FD}}$ values are seen due to the presence of fluvial fans from the eastern tributaries; these drain from the adjoining Hidden Lake Formation. In contrast, low $\mathrm{MS}_{\mathrm{LF}}$ and high $\mathrm{MS}_{\mathrm{FD}}$ values are characteristic in the upper reaches of the Algal and Dirty streams, which run through the Hidden Lake Formation or along the boundary between the Hidden Lake and Santa Marta formations. Both of these formations are known for their chemically altered and weathered volcanic components, associated with the Late Cretaceous volcanism on the Antarctic Peninsula (Olivero et al. 1986, Whitham et al. 2006). The two lowermost bedload samples from Algal Stream, which are located above the Mendel Formation basement, are transitory between the two above-mentioned cases with low $\mathrm{MS}_{\mathrm{LF}}$ and moderate $\mathrm{MS}_{\mathrm{FD}}$. This is because the Mendel Formation is composed of a mixture of glacigenic and glaciomarine sediments (Nývlt et al. 2011).

Similar to its magnetic properties, the chemical composition of the bedload reflects the differences in basement lithology. The bedload samples from the Bohemian Stream have a high Ca concentration, $\mathrm{Al} / \mathrm{Si}$ ratio and comparably lower values of other elemental ratios. In contrast, the other studied ratios $(\mathrm{K} / \mathrm{Ca}, \mathrm{Zr} / \mathrm{Ti}$, and $\mathrm{Rb} / \mathrm{Sr}$ ) have higher values for the Algal and Dirty streams sediments. This same trend has also been seen in the suspended sediment of these streams by Kavan et al. (2017) and shows a chemical relationship with the underlying Cretaceous strata in these catchments. Furthermore, Kavan et al. (2017) also showed that the volcanic rocks of the James Ross Island Volcanic Group are of limited importance to the composition of suspended sediments in the studied catchments. Indeed, the smaller range of data for bedload, as presented in Fig. 5, suggests even less influence of volcanic rocks on sediment composition.

The petrophysical and geochemical properties of the studied samples analysed in this study resemble the underlying geological units. The transport of the material from the neighbouring geological units is only visible for samples located in the middle reaches of the Bohemian Stream (samples 122-124). These samples show evidence of mixing with more distal sediments transported to the main valley of the Bohemian Stream by the Dirty Stream, which forms several flat fluvial fans on the floor of the main valley, and a minimum transport distance of $300-500 \mathrm{~m}$ could be expected. Similarly, sample 144 petrophysically and geochemically resembles a bedrock from the upper reaches of the Algal Stream, despite lying $\sim 100 \mathrm{~m}$ within the Mendel Formation. However, sample 145 located further downstream (Fig. 2) has a different composition that resembles its underlying bedrock (the Mendel Formation).

These results clearly show that the fluvial transport of the bedload fraction $<2 \mathrm{~mm}$ in size is strongly limited in the studied catchments, and their petrophysical and geochemical properties generally resemble the underlying geological units. In contrast, suspended sediment loads (as presented in Fig. 5) show a greater lithological variability; indicative of multiple source rocks and sediment mixing. The same observation was documented by Kavan et al. (2017), who noted that this was due to the input of volcanic rocks from the James Ross Island Volcanic Group (Fig. 5). 


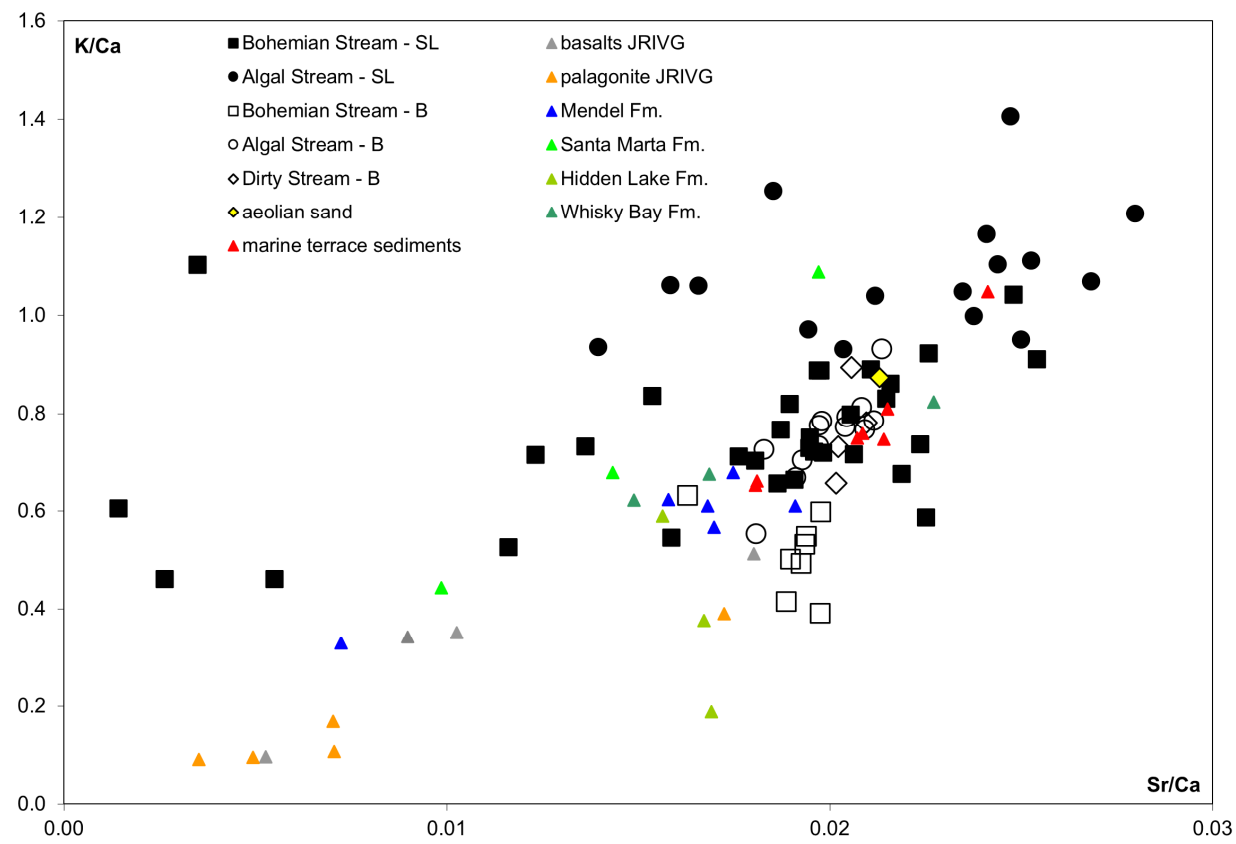

Fig. 5. Comparison of $\mathrm{Sr} / \mathrm{Ca}$ vs. $\mathrm{K} / \mathrm{Ca}$ values for Algal, Bohemian, and Dirty streams bedload (B) samples with suspended load (SL) of Algal, and Bohemian streams and the main geological units cropping out in both catchments from Kavan et al. (2017).

\section{Conclusions}

The data presented have shown a relationship between bedload and the underlying geological units. High values of massspecific magnetic susceptibility are typical, especially for the Bohemian Stream bedload. In contrast, frequency-dependent magnetic susceptibility showed higher values in Algal, and Dirty streams bedload samples, which corresponds with sources from the underlying Hidden Lake and Santa Marta formations and is typical for weathered Mesozoic volcanic rocks, which are more common in these formations. Similarly, the $\mathrm{Rb} / \mathrm{Sr}$ and $\mathrm{Zr} / \mathrm{Ti}$ ratios were found to be higher in the Algal and Dirty streams bedload, which provides evidence of chemical weathering. In comparison, the Bohemian Stream bedload showed high $\mathrm{Al} / \mathrm{Si}$ and $\mathrm{Ca} / \mathrm{Sr}$ ratios, typical for less chemically weathered siliciclastic sedimentary rocks.

The back-arc volcanic rocks of James Ross Island Volcanic Group are not important constituents of bedload material in the Algal and Bohemian catchments; the underlying Cretaceous marine sedimentary rocks of the James Ross Basin are more important constituents. This study has also shown that the fluvial transport of the bedload is limited under current discharge and water availability conditions as evidenced by its petrophysical and geochemical similarities with underlying geological units. This differs from the suspended load of the same streams, which is more mixed and indicates greater transport distances through the entire catchment. 


\section{References}

AltunkaynaK, S., Aldanmaz, E., GÜRaslan, I.N., ÇalişKanoĞLu, A. Z., ÜNal, A. and NÝvlt, D. (2018): Lithostratigraphy and petrology of Lachman Crags and Cape Lachman lava-fed deltas, Ulu Peninsula, James Ross Island, North-Eastern Antarctic Peninsula: Preliminary results. Czech Polar Reports, 8: 60-83.

Ambrožová, K., LÁsKa, K. and KaVAn, J. (2020): Multi-year assessment of atmospheric circulation and impacts on air temperature variation on James Ross Island, Antarctic Peninsula. International Journal of Climatology, 40: 1526-1541.

Cook, A. J., Vaughan, D. G. (2010): Overview of areal changes of the ice shelves on the Antarctic Peninsula over the past 50 years. The Cryosphere, 4: 77-98.

Davies, B. J., Glasser, N. F., Carrivick, J. L., Hambrey, M. J., Smellie, J. L. and NÝvlt, D. (2013): Landscape evolution and ice-sheet behaviour in a semi-arid polar environment: James Ross Island, NE Antarctic Peninsula. Geological Society London, Special Publications, 381: 353-395.

Dearing, J. A., Dann, R. J. L., Hay, K., Lees, J. A., Loveland, P. J., Maher, B. A. and O'Grady, K. (1996): Frequency-dependent susceptibility measurements of environmental materials. Geophysical Journal International, 124: 228-240.

ENGEL, Z., NÝVLT, D. and LÁsKA, K. (2012): Ice thickness, areal and volumetric changes of Davies Dome and Whisky Glacier (James Ross Island, Antarctic Peninsula) in 1979-2006. Journal of Glaciology, 58: 904-914.

FALK, U., Silva-Busso, A. (2021): Discharge of groundwater flow to the Potter Cove on King George Island, Antarctic Peninsula. Hydrology and Earth System Sciences, 25: 3227-3244.

Glasser, N. F., Davies, B. J., Carrivick, J. L., Rodés, A., Hambrey, M. J., Smellie, J. L. and DOMACK, E. (2014): Ice-stream initiation, duration and thinning on James Ross Island, northern Antarctic Peninsula. Quaternary Science Reviews, 86: 78-88.

HrbÁČEK, F., LÁSKA, K. and EnGEL, Z. (2016). Effect of snow cover on the active-layer thermal regime - a case study from James Ross Island, Antarctic Peninsula. Permafrost and Periglacial Processes, 27(3): 307-315.

HrbÁČEK, F., NÝvlt, D. and LÁSKA, K. (2017): Active layer thermal dynamics at two lithologically different sites on James Ross Island, Eastern Antarctic Peninsula. Catena, 149: 592-602.

HrbáČEK, F., NÝvlt, D., LÁSkA, K., KŇAŽKovÁ, M., KAmpovÁ, B., ENGEl, Z., Oliva, M. and Mueller, C. W. (2019): Permafrost and active layer research on James Ross Island: An overview. Czech Polar Reports, 9: 20-36.

HrbÁČEK, F., UXA, T. (2020): The evolution of a near-surface ground thermal regime and modelled active-layer thickness on James Ross Island, Eastern Antarctic Peninsula, in 20062016. Permafrost and Periglacial Processes, 31: 141-155.

Ineson, J. R., Crame, J. A. and Thompson, M. R. A. (1986): Lithostratigraphy of the cretaceous strata of West James Ross Island, Antarctica. Cretaceous Research, 7: 141-159.

Jennings, S. J. A., Davies, B. J., NÝvlt, D., Glasser, N. F., Engel, Z., Hrbáček, F., Carrivick, J. L., MLČOCh, B. and Hambrey, M. J. (2021): Geomorphology of Ulu Peninsula, James Ross Island, Antarctica. Journal of Maps, 17(2): 125-139.

Jennings, S. J. A., HAMBREY, M. J. (2021): Structures and deformation in glaciers and ice sheets. Reviews of Geophysics, 59.

Johnson, J. S., Bentley, M. J., Roberts, S. J., Binnie, S. A. and Freeman, S. P. H. T. (2011): Holocene deglacial history of the northeast Antarctic Peninsula - A review and new chronological constraints. Quaternary Science Reviews, 30: 3791-3802.

Kavan, J., Ondruch, J., NÝvlt, D., HrbáČEK, F., CARrivick, J. and LÁsKa, K. (2017): Seasonal hydrological and suspended sediment transport dynamics in proglacial streams, James Ross Island, Antarctica. Geografiska Annaler: Series A, Physical Geography, 99: 38-55.

KŇAŽKOVÁ, M., HrbÁČEK, F., KAVAN, J. and NÝVlt, D. (2020): Effect of hyaloclastite breccia boulders on meso-scale periglacial-aeolian landsystem in semi-arid Antarctic environment, James Ross Island, Antarctic Peninsula. Geographical Research Letters, 46: 7-31. 
KŇAŽKOVÁ, M., NÝVLT, D. and HRBÁČEK, F. (2021): Slope processes connected with snow patches in semi-arid ice-free areas of James Ross Island, Antarctic Peninsula. Geomorphology, 373: $1-10$.

MlČOCh, B., NÝVlt, D. and MiXA, P. (eds.; 2020): Geological map of James Ross Island Northern Part. 1: 25 000, Czech Geological Survey. Praha.

NehyBA, S., NÝvlt, D. (2014): Deposits of pyroclastic mass flows at Bibby Hill (Pliocene, James Ross Island, Antarctica). Czech Polar Reports, 4: 103-122.

NÝvlt, D., KoŠLER, J., MLČOCh, B., MiXA, P., LisÁ, L., Bubík, M. and Hendriks, B. W. H. (2011): The Mendel Formation: Evidence for Late Miocene climatic cyclicity at the northern tip of the Antarctic Peninsula. Palaeogeography, Palaeoclimatology, Palaeoecology, 299: 363-384.

NÝvlt, D., Braucher, R., Engel, Z. and Mlčoch, B. (2014): Timing of the Northern Prince Gustav Ice Stream retreat and the deglaciation of northern James Ross Island, Antarctic Peninsula during the last glacial-interglacial transition. Quaternary Research, 82: 441-449.

NÝvlt, D., NÝvltová Fišáková, M., Barták, M., Stachoň, Z., Pavel, V., MlČoch, B. and LÁSKA, K. (2016): Death age, seasonality, taphonomy and colonization of seal carcasses from Ulu Peninsula, James Ross Island, Antarctic Peninsula. Antarctic Science, 28: 1-14.

Olivero, B. E., Scasso, R. A. and Rinaldi, C. A. (1986): Revision of the Marambio Group, James Ross Island, Antarctica. Instituto Antártico Argentino, Buenos Aires, $30 \mathrm{p}$.

OnDRÁČKOVÁ, L., SuRIAN, N., NÝVlt, D. and StuChlíK, R. (2020): Downstream variability of channel morphology and bed material in the braided Keller River, James Ross Island, Antarctica. Geografia Fisica e Dinamica Quaternaria, 43(2): 195-206.

Palerme, C., Genthon, Ch., Claud, Ch., Kay, J. E., Wood, N. B. and L'Ecuyer, T. (2017): Evaluation of current and projected Antarctic precipitation in CMIP5 models. Climate Dynamics, 48: 225-239.

PaOlo, F. S., Fricker, H. A. and Padman, L. (2015): Ice sheets. Volume loss from Antarctic ice shelves is accelerating. Science, 348: 327-331.

Pritchard, H., Vaughan, D. (2007): Widespread acceleration of tidewater glaciers on the Antarctic Peninsula. Journal of Geophysical Research Atmospheres, 112: 1-10.

Ruiz-Fernández, J., Oliva, M., NÝvlt, D., Cannone, N., García-Hernández, C., Guglielmin, M., Hrbáčex, F., Roman, M., Fernández, S., López-Martínez, J. and Antoniades, D. (2019): Patterns of spatio-temporal paraglacial response in the Antarctic Peninsula region and associated ecological implications. Earth-Science Reviews, 192: 379-402.

Seehaus, T., Cook, A., Silva, A. B. and Braun, M. (2018): Changes in glacier dynamics at the northern Antarctic Peninsula since 1985. The Cryosphere, 12: 577-594.

Siegert, M., Atkinson, A., Banwell, A., Brandon, M., Convey, P., Davies, B., Downie, R., Edwards, T., Hubbard, B., Marshall, G., Rogelj, J., Rumble, J., Stroeve, J. and Vaughan, D. (2019): The Antarctic Peninsula under a $1.5^{\circ} \mathrm{C}$ global warming scenario. Frontiers in Environmental Science, 7: 1-6.

Smellie, J. L., Johnson, J. S. and Nelson, A. E. (2013): Geological map of James Ross Island. 1. James Ross Island Volcanic Group. BAS GEOMAP 2 series, sheet 5, 1: 125 000. British Antarctic Survey.

van Wessem, J. M, Ligtenberg, S. R. M., Reijmer, C. H., van de Berg, W. J., van den Broeke, M. R., Barrand, N. E., Thomas, E. R., Turner, J., Wuite, J., Scambos, T. A. and van MeiJgaARd, E. (2016): The modelled surface mass balance of the Antarctic Peninsula at $5.5 \mathrm{~km}$ horizontal resolution. The Cryosphere, 10: 271-285.

Vaughan, D., Mulvaney, R., Marshall, G. J. and Hodgson, D. A. (2003): Recent rapid regional climate warming on the Antarctic Peninsula. Climatic Change, 60: 243-274.

Whitham, A. G., Ineson, J. R. and PirRie, D. (2006): Marine volcaniclastics of the Hidden Lake Formation (Coniacian) of James Ross Island, Antarctica: An enigmatic element in the history of a back-arc basin. Geological Society London, Special Publications, 258: 21-47.

\section{Web sources / Other sources}

[1] Czech Geological Survey (CGS) (2009): James Ross Island - Northern Part. Topographic map $1: 25$ 000. First edition. Praha, Czech Geological Survey. ISBN 978-80-7075-734-5. 